\title{
Agriculture and food security in selected countries in Sub-Saharan Africa: diversity in trends and opportunities
}

\author{
Jan de Graaff • Aad Kessler • Jan Willem Nibbering
}

Received: 16 December 2010/Accepted: 24 March 2011 /Published online: 15 April 2011

(C) The Author(s) 2011. This article is published with open access at Springerlink.com

\begin{abstract}
The World Food Summit in 1996 set the goal of reducing by half the numbers of malnourished people in the world by 2015. It is unlikely that this will be reached, and particularly not in Sub-Saharan Africa (SSA). Food imports in SSA have increased in the past 40 years, since domestic production could not keep up with population growth. Several studies have reported about this stagnating food production in SSA. However, this region encompasses a large number of countries, with a great variety of agroecological zones and large differences in land, labour and other resources. The objectives of this paper are to analyse agricultural production and food security in eight countries in Sub-Saharan Africa over the past 40 years, and to investigate to what extent these countries have followed different agricultural development pathways and are faced with different constraints. The analysis is largely based on statistical data, mainly from FAO, and on other information from various national and international sources. It shows that some of these countries have struggled to achieve and maintain overall national food security, while others have been able to achieve more than that and increased production at a faster rate than population growth. It subsequently analyzes major development constraints, with regard to labour, land and water, and institutions, pinpoints certain positive developments that have taken place in some of the countries and looks at opportunities for the respective countries to improve their food situation. One of its conclusions is that more attention should be paid to country specific constraints and opportunities.
\end{abstract}

J. de Graaff $(\bowtie) \cdot$ A. Kessler

Wageningen University,

Wageningen, Netherlands

e-mail: jan.degraaff@wur.nl

J. W. Nibbering

Ministry of Foreign Affairs,

The Hague, The Netherlands
Keywords Agriculture · Food security · Sub-Saharan Africa $\cdot$ Development $\cdot$ Natural resources

\section{Introduction}

The 1996 World Food Summit (WFS) set the goal of reducing by half the number of malnourished people in the world by 2015 (FAO 2006). Although the proportion of hungry people has declined over the last 40 years, the reduction in the absolute number of undernourished has been low, and it is unlikely that the WFS goal will be achieved. The biggest challenge is to achieve this in SubSaharan Africa (SSA). About one third of this region's rapidly growing population is currently food insecure, with cereal imports having increased from $5 \%$ of total consumption in the 1960 s - when most countries became independent - to $25 \%$ in the early 2000 s. Food aid is indispensable, although declining and varying greatly from country to country. In the early 2000 s, it still accounted for about $5 \%$ of cereal consumption (Kidane et al. 2006).

An important reason for this dependence on food imports is the fact that average cereal yields have only marginally increased over the period 1961-2001, and were in 2001 only $1 \mathrm{MT} \mathrm{ha}^{-1}$, while in Asia and the Pacific cereal yields increased over the same period from about 1.2 to $3.2 \mathrm{MT} \mathrm{ha}^{-1}$ (Jones 2006). In explaining this difference, Karshenas (1999) showed that in 1965 there were already large differences in the use of production factors (percentage of land cultivated, labour, fertilisers, irrigation and tractors) in agriculture between Asia and SSA, and that these differences, with the exception of labour, widened until 1995.

In contrast with these yield differences, the IAASTD (2009) report showed that the overall average farm size in Africa and Asia was, in 2005, actually equal at only 1.6 ha. 
In analysing the situation in SSA, it is often assumed that all SSA countries have common structural economic features that negatively affect agricultural production. Some of the common features, mentioned in a recent publication by UNDP (2010), are among others:

- low gross domestic product (GDP) per capita (less than 1,000 US\$ per year) and a high share of agriculture in GDP (close to $50 \%$ );

- half of the agricultural land lying in arid and semi-arid (dryland) zones, often with poor quality soils (Ehui and Pender 2005);

- over-reliance on rain-fed agriculture (less than $5 \%$ of land is irrigated), which is highly vulnerable to fluctuations in rainfall;

- much land degradation, including wind and water erosion and high levels of soil mining, with very low levels of fertilization (Stoorvogel and Smaling 1990);

- much malnutrition and a high prevalence of diseases, in particular HIV/AIDS, resulting in low life expectancy and labour shortages;

- high transport costs, small markets and lack of infrastructure;

- a high rate of population growth, close to $3 \%$ per annum;

- a high percentage of the population living below the poverty line, and consequently high dependency on (food) aid.

While these generalisations are valid for the SSA region if viewed from a world-wide perspective, there are huge differences among SSA countries, first of all in agroecological conditions and in the quantity and quality of land and other natural resources. SSA has a variety of agroecological zones ranging from humid to arid: Sahelian countries consist mostly of dryland or (semi-) arid land, while countries like Rwanda and Malawi are (sub-) humid and do not have dryland. Soil quality is, in general, poor in many areas and may have further deteriorated through soil mining, while some countries e.g. Kenya and Rwanda, have areas with better (often volcanic) soils.

There is also great variation in terms of socio-economic (development) indices among SSA countries as shown in Table 1 for eight selected SSA countries. Ethiopia and Malawi have very low GDP per capita values which are far below those of Cameroon and South Africa. The share of agriculture in GDP is much higher in Ethiopia and Rwanda than in South Africa, Senegal and Cameroon. Ethiopia and to a lesser extent Rwanda show a low intake of calories, a high level of malnutrition despite receiving much food aid in the 1980s and 1990s, as compared to the West African countries of Burkina Faso and Senegal. Prevalence of HIV/ AIDS is very high in Malawi and South Africa, with $14 \%$ and over $20 \%$, respectively, of the adult population affected, compared to about $1 \%$ in Senegal. In most countries life expectancy at birth is now around 50 years, except for Senegal where it has increased to 63 years (World Bank 2009).

The objectives of this paper are to analyse agricultural production and food security in eight countries in Sub-Saharan Africa over the past 40 years, and to investigate to what extent these countries have followed different agricultural development pathways and are faced with different constraints. Over the years, various publications have dealt with agricultural development and food security in SSA, but these have not made a comparison between particular countries, and have not covered such a long period (World Bank 1989; Kidane et al. 2006; World Bank 2008a). Some publications focused more on science, technology and knowledge exchange

Table 1 Development indicators for eight selected Sub-Saharan countries

\begin{tabular}{|c|c|c|c|c|c|c|c|c|}
\hline Country & $\begin{array}{l}\text { Human Devel. Index } \\
2006\end{array}$ & $\begin{array}{l}\text { GDP/capita }{ }^{1)} \\
2007 \\
\text { US\$ }\end{array}$ & $\begin{array}{l}\text { Share agricul. } \\
\text { In GDP } \\
2004 \\
\%\end{array}$ & $\begin{array}{l}\text { Kcal/ } \\
\text { capita/day } \\
2003 \\
\text { Kcal }\end{array}$ & $\begin{array}{l}\text { Food aid/capita/ } \\
\text { annum } \\
03-05 \\
\mathrm{Kg}\end{array}$ & $\begin{array}{l}\text { Malnu-trition } \\
2001 \\
\%\end{array}$ & $\begin{array}{l}\text { Adult HIV/ } \\
\text { Aids } \\
2006 \\
\%\end{array}$ & $\begin{array}{l}\text { Annual popul. } \\
\text { Growth } \\
2007 \\
\%\end{array}$ \\
\hline Burkina Faso & 0.372 & 430 & 31 & 2,515 & 2.8 & 19 & 4.2 & 2.9 \\
\hline Senegal & 0.502 & 830 & 18 & 2,374 & 2.5 & 22 & 0.8 & 2.8 \\
\hline Ethiopia & 0.389 & 220 & 44 & 1,858 & 18.4 & 44 & 4.4 & 2.5 \\
\hline Kenya & 0.532 & 640 & 28 & 2,154 & 4.5 & 32 & 6.7 & 2.6 \\
\hline Rwanda & 0.435 & 320 & 42 & 2,070 & 4.9 & 35 & 5.1 & 2.8 \\
\hline Malawi & 0.457 & 250 & 38 & 2,125 & 9.2 & 32 & 14.2 & 2.5 \\
\hline Cameroon & 0.514 & 1,050 & 21 & 2,285 & 0.5 & 24 & 6.9 & 2.0 \\
\hline South Africa & 0.670 & 5,720 & 3 & 2,962 & - & - & 21.5 & 0.9 \\
\hline SSA & 0.495 & 951 & & & & & & 2.4 \\
\hline
\end{tabular}

Kidane et al. 2006; http://www.earthtrends.wri.org; Faostat 2009; World Bank 2008a, 2009

${ }^{1)}$ In terms of purchasing power parity (PPP) figures are much higher for all countries 
(IAASTD 2009) and some looked more into economic and trade aspects and policies (Boussard et al. 2005).

In "Trends in agriculture (1966-2006)" and "Trends in food security (1966-2006)" of this paper we explore trends in agriculture and trends in food security, respectively, for the 8 countries in the period 1966-2006. They show that apart from various similarities there is also a great diversity within the countries, giving rise to specific challenges and opportunities. We acknowledge that food insecurity is not just a failure of agriculture to produce enough food, but, more generally, a failure of livelihoods, with insufficient paid work in other sectors to guarantee access to sufficient food (Devereux and Maxwell 2001) and also a failure of development policies. We realise that farming and household livelihood systems in Africa are very complex, with farmers, particularly in dryland areas, being involved in a range of activities outside their farm, such as work on other farms, in forestry, trade and industry, artisan activities, goldmining, short and long term migration, etc. However, the focus in this paper will be on agricultural production and its performance and dynamics. We think this focus is justified because, first of all, agriculture is still the major means of support for the majority of the population of SSA. Secondly, the developments in agricultural production and the various forms in which it takes place in SSA are closely interrelated with the wider economy and can legitimately be studied as a subsystem of it. Moreover, it is only in this manner that the diversity in agricultural production in SSA can be best shown and it is to bring out this very diversity that is one of the purposes of this paper. So in this paper we have 'ring-fenced' agriculture from broader economic, social or institutional developments but where we believe such developments influence agriculture, they will be pointed out. However, not all of this diversity may seem to have a direct bearing on food security. Yet we think it is useful to give a full picture. Others may find this useful information to be worked upon further. Also, in discussing trends, the paper will not deal much with institutional settings, infrastructure and social capital but these matters are to some extent included in our discussion of the constraints in agricultural development, which is the topic of "Major constraints in crop production" of the paper. In "Opportunities and challenges" we discuss a number of opportunities and challenges by looking at some successful or promising interventions. In doing so, we make use, to the extent possible, of the insights obtained from the analysis of the trends in "Trends in agriculture (1966-2006)" and "Trends in food security (1966-2006)".

The aforementioned eight countries are central in this paper and are considered to be representative for SSA and its diversity. Four countries have a low (below 0.500) Human Development Index (HDI) and four have medium HDI ratings. The countries are well spread over West (3),
East (3) and Southern (2) Africa and also over major agroecological zones (Figure 1). Four of the countries are landlocked. With the exception of South Africa, all are agriculture-based, low income, developing countries.

While all eight countries have specific features, some countries have more in common with each other than others and are likely to face similar challenges. For the sake of comparison, and given the focus on agriculture in this paper, the countries are clustered on the basis of potential for agricultural production, i.e. area of dryland as percentage of total land area. Clusters of countries in that respect are (1) Burkina Faso (100\% dryland) and Senegal (92\%); (2) Ethiopia (57\%) and Kenya (67\%), and (3) Rwanda and Malawi (both without dryland). Cameroon (13\% dryland) is a separate case, with climate ranging from humid in the south to arid in the north. South Africa with $67 \%$ dryland stands out in various aspects and has a much higher HDI and GDP per capita.

The idea of clustering is to some extent also supported by the farming systems study undertaken by Dixon et al. (2001). Burkina Faso and Senegal are both Sahel countries where the agro pastoral millet/sorghum system dominates. Ethiopia and Kenya can be characterised as countries with highland temperate mixed farming and large pastoral zones, or as having both high and low potential zones. Rwanda and Malawi have in common the fact that root crops play an important role in the farming systems. Cameroon has forestbased, tree crop based and cereal-root crop farming systems. South Africa stands out with its enormous difference between the large commercial and smallholder sectors. The clustering correlates well with population density (very high in Rwanda and Malawi, and low in Cameroon and South Africa) and in reverse order with urbanization rate.

The analysis in this paper is to a large extent based on statistical data, and mainly but not exclusively, from FAOSTAT. These data are derived from national survey data, and it is realised that data on area cultivated and crop yields can never be really accurate (de Graaff et al. 1999). Although these data may have their weaknesses, they have for long been compiled in a careful and consistent way and therefore provide sufficient evidence to discern certain trends over a 40 year period. These data do not show differences within countries, and do not (sufficiently) cover informal and illegal production and trade. In order to obtain a more complete picture of the situation in the respective countries, many other references and the experiences of the authors in several of the countries have been used.

\section{Trends in agriculture (1966-2006)}

Because of the high incidence of arid conditions and poor soils, large parts of the land area in SSA are not suitable for arable cultivation, but the percentage of suitable land varies 


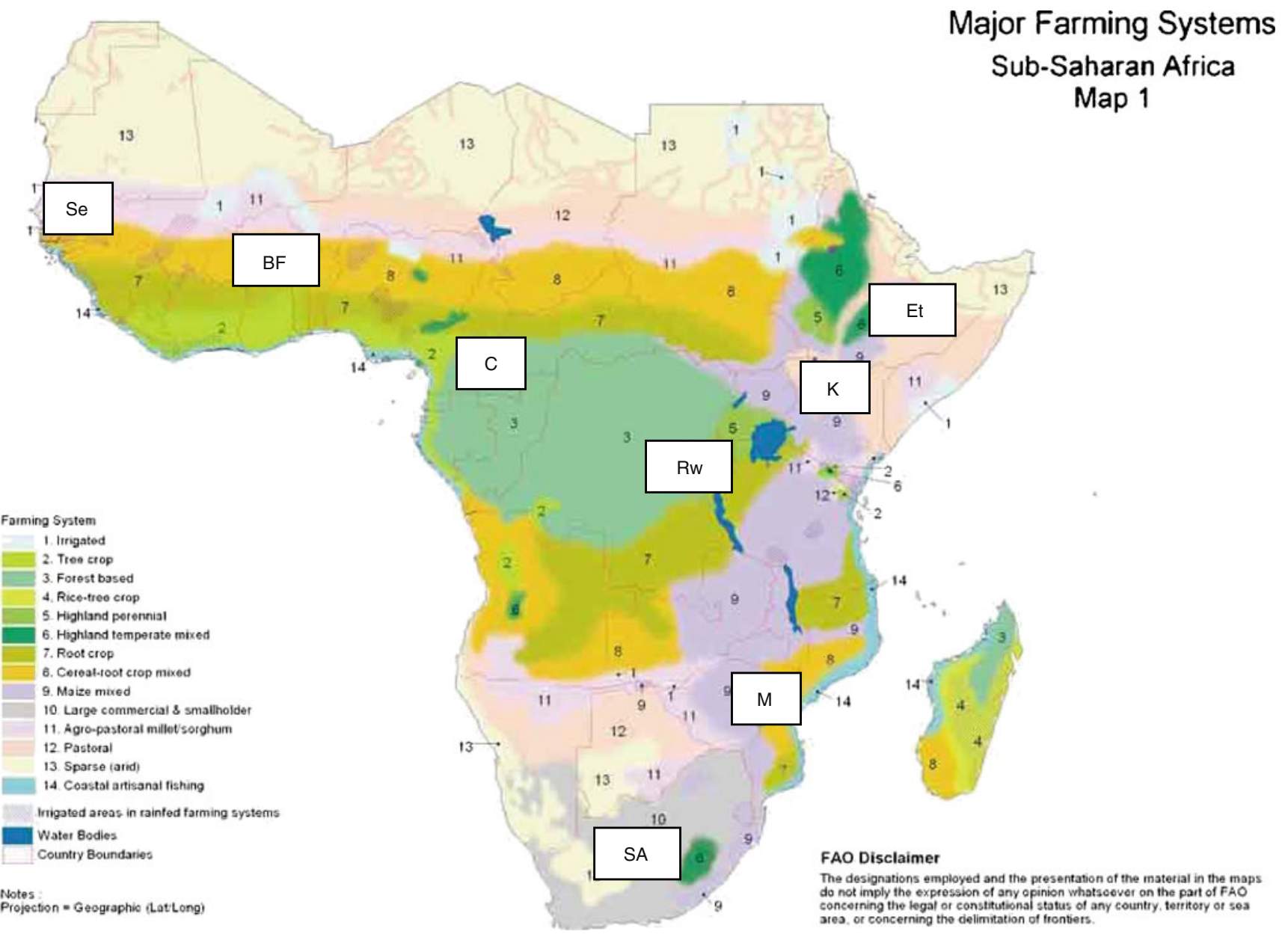

Fig. 1 Sub-Saharan Africa, with selected countries and major farming systems, as derived from Dixon et al. 2001. (Selected countries are: BF = Burkina Faso; $\mathrm{C}=$ Cameroon; Et = Ethiopia; $\mathrm{K}=$ Kenya; $\mathrm{M}=$ Malawi; Rw = Rwanda; $\mathrm{SA}=$ South Africa; Se = Senegal)

strongly by country. As so much of the land is unsuitable, the population density in the suitable agricultural zones is relatively high, and the average amount of farm land per person is very low in most countries. Table 2 shows how heterogeneous the situation is with regard to land use in the selected SSA countries. On average about half of the land is considered to be agricultural, including pastures and rangeland, but in 2005 this varied from a low $20 \%$ in Cameroon to a high $80 \%$ in Rwanda and South Africa. Only in Cameroon, Malawi and Rwanda is most agricultural land used for arable and permanent crops; in the other, more semi-arid, countries, and in particular South Africa, much land is unfit for crops and can only be used for pasture and rangeland.

The increase in agricultural area between 1966 and 2005 has been fastest in Malawi, Rwanda and Burkina Faso for both arable and permanent cropland. However, the expansion of agricultural land has been far from keeping pace with population growth in these three countries. In all countries total population has more or less tripled in the period 1966-2005. Although urbanization has somewhat slowed down population growth in the rural areas, the high population growth has drastically reduced the availability of agricultural land per capita.

Since farmers are mostly occupied with growing arable and permanent crops, it is possible to calculate the availability of cropland per person. In 1966 these figures were already very low for most countries, except South Africa and Cameroon, and they have declined further to a mere $0.2-0.4$ ha per person. While it was already extremely low and has decreased even further in Rwanda (only 0.18 ha per person), it has decreased rapidly in Ethiopia and Kenya in this period (Table 2).

This general decline in per capita access to crop land in this 40 year period raises the question whether higher yields in this same period have been able to off-set the reduction in the per capita availability of cropland. 'Agricultural land' in Table 2 includes all crop land, but also pastures and fallow land.

To get an impression of the trend in average crop yields, Table 3 shows for a selection of major crops the trend in area cultivated, total production and yields. In many SSA 
Table 2 Agricultural land use and land availability in eight selected countries in Sub-Saharan Africa (1966-2005)

\begin{tabular}{|c|c|c|c|c|c|c|c|c|c|c|}
\hline \multirow[t]{3}{*}{ Country } & \multicolumn{2}{|c|}{$\begin{array}{l}\text { Agricultural land }{ }^{1)} \text { as } \% \\
\text { of total land }\end{array}$} & \multicolumn{2}{|c|}{$\begin{array}{l}\text { Arable \& perm. crops }{ }^{1)} \text {, as } \\
\% \text { of land }\end{array}$} & \multirow{2}{*}{\multicolumn{2}{|c|}{$\begin{array}{l}\begin{array}{l}\text { Overall population } \\
\text { density }\end{array} \\
\mathrm{Pp} / \mathrm{km} 2\end{array}$}} & \multirow{2}{*}{\multicolumn{2}{|c|}{$\begin{array}{l}\begin{array}{l}\text { Agricultural land } \\
\text { per person }\end{array} \\
\mathrm{Ha} / \mathrm{pp}\end{array}$}} & \multirow{2}{*}{\multicolumn{2}{|c|}{$\begin{array}{l}\begin{array}{l}\text { Arable \& perm. land } \\
\text { per person }^{2)}\end{array} \\
\mathrm{Ha} / \mathrm{pp}\end{array}$}} \\
\hline & \multicolumn{2}{|l|}{$\%$} & \multicolumn{2}{|l|}{$\%$} & & & & & & \\
\hline & 1966 & 2005 & 1966 & 2005 & 1966 & 2005 & 1966 & 2005 & 1966 & 2005 \\
\hline Burkina Faso & 30 & 40 & 8 & 18 & 18 & 52 & 1.8 & 0.9 & 0.49 & 0.40 \\
\hline Senegal & 42 & 43 & 12 & 13 & 20 & 63 & 2.4 & 1.0 & 0.69 & 0.31 \\
\hline Ethiopia & 53 & 34 & 12 & 14 & 26 & 81 & 2.3 & 0.5 & 0.49 & 0.22 \\
\hline Kenya & 44 & 47 & 7 & 10 & 17 & 64 & 2.9 & 1.1 & 0.46 & 0.23 \\
\hline Malawi & 33 & 49 & 13 & 29 & 43 & 144 & 0.8 & 0.5 & 0.35 & 0.38 \\
\hline Rwanda & 55 & 79 & 27 & 60 & 134 & 384 & 0.4 & 0.2 & 0.21 & 0.18 \\
\hline Cameroon & 17 & 20 & 12 & 15 & 13 & 39 & 1.6 & 1.2 & 1.16 & 0.94 \\
\hline South-Africa & 80 & 82 & 11 & 13 & 17 & 40 & 11.1 & 16.7 & 1.45 & 2.78 \\
\hline Average & 53 & 51 & 11 & 14 & 21 & 61 & 3.3 & 1.4 & 0.7 & 0.4 \\
\hline
\end{tabular}

1)Agricultural land including pasture land and fallow land

2)Agricultural land, respectively arable and permanent crop land, divided by agricultural population

FAOSTAT 2009

countries increase in area cultivated is constrained by climatic conditions. Yield increases are often constrained by a lack of improved varieties, fertilisers and other inputs and declining soil fertility (Henao and Baanante; Table 10). With 12 different crops the number of major crops that have been selected is lowest in the Sahel countries and it is highest in Cameroon which has 23 different major crops. Cameroon has the largest range of agro-ecological zones and therefore has a great variety of food- and other crops (Westphal et al. 1985).

Table 3 shows that yields for these major crops have generally increased during that period, but at different rates. FAOSTAT (2009) shows that average yields tripled in
Malawi, that they more or less doubled in most other countries and that they only increased marginally in Rwanda.

Also, it can be concluded from Table 3 that yield increases in these eight countries have generally contributed more to total production than increases in area cultivated; this seems in particular to be the case in the first 20 years. A clear exception is Rwanda, where the area cultivated has expanded enormously in the period 1966-1986, and where the area expansion rate is proportionately almost equal to the increase in total production over the whole period 1966-2006, as yields per hectare hardly increased for most crops in that period.

Table 3 Cultivated area and production of major crops in eight selected Sub-Saharan countries: 1966-1986 and $1986-2006$

\begin{tabular}{|c|c|c|c|c|c|c|c|c|c|}
\hline & \multirow[t]{2}{*}{ No of crops } & \multicolumn{3}{|c|}{$\begin{array}{l}\text { Increase area cultivated } \\
\text { (index; first year }=100 \text { ) }\end{array}$} & \multirow{2}{*}{$\begin{array}{l}\text { Increase yields } \\
1966-06 \\
(1966=100)\end{array}$} & \multicolumn{3}{|c|}{$\begin{array}{l}\text { Increase in production* } \\
\text { (index; first year }=100 \text { ) }\end{array}$} & \multirow{2}{*}{$\begin{array}{l}\text { Increase population } \\
1966-06 \\
(1966=100)\end{array}$} \\
\hline & & 1966-1986 & 1986-2006 & 1966-2006 & & 1966-1986 & 1986-2006 & 1966-2006 & \\
\hline Burkina $\mathrm{F}$ & 12 & 125 & 147 & 184 & 237 & 213 & 205 & 436 & 286 \\
\hline Senegal & 12 & 88 & 91 & 80 & 156 & 138 & 103 & 142 & 310 \\
\hline Ethiopia & 17 & 75 & 185 & 140 & 210 & 121 & 242 & 294 & 285 \\
\hline Kenya & 21 & 148 & 136 & 202 & 167 & 256 & 132 & 338 & 371 \\
\hline Malawi & 17 & 122 & 144 & 175 & 322 & 226 & 250 & 564 & 333 \\
\hline Rwanda & 19 & 192 & 137 & 264 & 107 & 214 & 132 & 283 & 287 \\
\hline Cameroon & 23 & 126 & 129 & 163 & 169 & 190 & 145 & 275 & 294 \\
\hline S. Africa & 18 & 118 & 57 & 67 & 272 & 143 & 108 & 155 & 238 \\
\hline Average & & 110 & 118 & 130 & 180 & 165 & 142 & 234 & \\
\hline
\end{tabular}

FAOSTAT 2009. * Production of all these crops considered together in tonnes 
While the two periods in Table 3 show on average a slow and slight increase of area cultivated, with $10 \%$ and $18 \%$ respectively, for the eight countries there are large differences between them. In Ethiopia the first period showed a strong decline and the second period almost a doubling of cultivated area, which somehow seems to coincide with the two different political regimes in those periods. In South Africa, on the other hand the area cultivated declined sharply in the second period.

Due to the combined effect of the increase in cultivated area and increase in yields, the total production went up in all countries in both periods. However, production increases in Senegal and South Africa were very low in the second period, and the increase in production lagged far behind population increase, as a consequence. The different results can for Senegal be attributed to its high rate of urbanization consequent upon which there was a drop in share of agriculture in GDP from $15 \%$ in 1960 to $7 \%$ in 2004. And the South African economy is no longer agriculture based, livestock production being more important than crop production (Vink and Kirsten 2003).

In Burkina Faso and Malawi the increase in production of major crops exceeded population growth whereas in Ethiopia, Rwanda, Kenya and Cameroon it kept more or less the same pace with population growth. Surprising (and possibly exaggerated) is the high yield and production increase in Malawi, but this seems largely due to a shift from production of grains to heavier crops, such as tubers, bananas and sugarcane (Table 4). A similar move towards tuber crops also took place in Rwanda in the 1980s (André and Platteau 1998).

Table 4 shows which three crops had the highest relative area expansion, and which three crops had the highest yield increases during 1966-2006. The types of crops that show a high area increase in each country and surprisingly also within the clusters are rather different, with the exception of Burkina Faso and Senegal. Sugarcane and cotton, both cash crops, feature most often; their total areas more than tripled, especially in Burkina Faso and Senegal. Sanders et al. (1996) already concluded that cotton and maize were impressive success stories of new technology and diffusion in the Sudano-Guinean zone of West Africa. Sugarcane areas increased in almost all countries, with the largest area in South Africa. The three crops shown for Rwanda are still of minor importance in this country, but they show a spectacular expansion. Although groundnut still occupies a large area, it has declined by more than $20 \%$ over the last 40 years in Rwanda, similar to the decline in coffee area.

Yields have increased for about two-thirds of the major crops in SSA and for $29 \%$ of these crops yields more than doubled between 1966 and 2006. Cotton and maize show up most often among the three crops with the highest yield increase. Yield decline was also analyzed. The lowest number of crops ( 2 out of 12 , or $17 \%$ ) showing a yield decline was found in the two driest countries, Burkina Faso and Senegal. The most densely populated country, Rwanda, showed the highest number of crops with a yield decline (12 out of 19 , or $63 \%$ ). In that country Irish potatoes and the minor crops rice and tea are clear exceptions in that regard.

The expansion of the area under cotton and the rise in cotton yields led to an enormous production increase of this crop in Burkina Faso and to a lesser extent in Senegal and Ethiopia. In Cameroon and Ethiopia banana production increased most. Other crops that showed a major production increase were sugarcane (Malawi, Cameroon, Senegal and South Africa), Irish potatoes (Cameroon and Malawi) and maize (Burkina Faso and Senegal, both non-traditional

Table 4 Crops with the highest increase in cultivated area and crops with the highest yields ${ }^{1}$ in eight selected countries in Sub-Saharan Africa, 1966-2006

\begin{tabular}{|c|c|c|c|c|c|c|c|}
\hline \multirow[t]{2}{*}{ Country } & \multirow[t]{2}{*}{ No of crops } & \multicolumn{3}{|c|}{$\begin{array}{l}\text { Crops with highest relative area increase from } \\
1966-2006 \text { in descending order }\end{array}$} & \multicolumn{3}{|c|}{$\begin{array}{l}\text { Crops with highest relative yield increase from } \\
1966-2006 \text { in descending order }\end{array}$} \\
\hline & & 1 & 2 & 3 & 1 & 2 & 3 \\
\hline Burkina F. & 12 & Cotton & Maize & Sesame & Cotton & Sw.pot. & Maize \\
\hline Senegal & 12 & Cotton & Maize & Sugarcane & Sw. pot. & Maize & Bananas \\
\hline Ethiopia & 18 & Banana & Cotton & Sw. pot. & Coffee & Millet & Wheat \\
\hline Kenya & 21 & Pineapple & Beans & Rice & $T e a$ & Sugarcane & Groundnut \\
\hline Malawi & 17 & Sugarcane & Potatoes & Cassava & Bananas & Cotton & Cassava \\
\hline Rwanda & 19 & Rice & Wheat & Tea & Rice & Tea & Potatoes \\
\hline Cameroon & 23 & Banana & Sugarcane & Potatoes & Maize & Cotton & Cocoa \\
\hline S. Africa & 18 & Soybean & Sunflower & Sugarcane & Wheat & Soybean & Potatoes \\
\hline
\end{tabular}

FAOSTAT 2009

${ }^{1)}$ Comparison between areas and yields in periods 1965-1967 and 2005-2007; cash crops in italics 
maize producers). However, all these crops are generally not the most important (food) crops that are grown in these countries, in terms of total area cultivated.

Among the crops showing a declining production were cassava and yam in Burkina Faso, coffee and millet in Cameroon, yam and soybean in Ethiopia, sisal and pyrethrum in Kenya, sorghum, maize and groundnut in Malawi, peas and pyrethrum in Rwanda, groundnut and cassava in Senegal, and groundnut and sorghum in South Africa. The latter is not surprising, since in South Africa groundnut, and to a lesser extent sorghum and some other grains and oilseeds, received less producer support in the late 1990s (Vink and Kirsten 2003).

While showing the general trends of average yields and total production for the respective countries and the differences between these countries over this long period, it should not be forgotten that there are also enormous differences in yields between farms and regions within each country. This is obvious in countries with very different agro-ecological zones (e.g. Kenya and Ethiopia), but also within the same agro-ecological zone yields may differ considerably between farms, as was for example shown for the Central Plateau in Burkina Faso (de Graaff 1996). There are also large differences in yield between different farm types, such as smallholders, medium-sized commercial farmers and large farms or estates, which are related to such factors as market access and use of inputs.

\section{Trends in food security (1966-2006)}

\section{Food crops}

Table 5 shows that most of the major crops - in terms of area cultivated - are food crops, with maize featuring strongly in all countries except Rwanda (where it ranks 7th). Sorghum and beans are also major crops in several countries. Root and tuber crops do not show up much as a major crop, although they feature prominently in the diet in several countries. This is because they have a much higher calorie content per ha than other crops (see below, Table 7).

Considering that people consume about $200 \mathrm{~kg}$ grainequivalent per year (and assuming some losses and sales) and that per person only 0.2 ha per person is available for grains in most countries (Table 2), this implies that average grain yields should be at least around $1000 \mathrm{~kg}$ per ha to reach self-sufficiency (at farm level). Table 6 shows that these levels were met in 2006 for maize in most countries (except Rwanda) and for sorghum only in half of the countries. But in this period the non-farming and urban population increased more than proportionally, putting a greater pressure on food producers to reach national selfsufficiency. While some producers are able to produce sizeable surpluses, many others are in fact net food purchasers. Dorward (2010) estimates that in East and Southern Africa about $50 \%$ of farmers are net food purchasers. Considering the lack of marketing and transport infrastructure in some countries, this implies that there could be at a certain moment both food shortages in some areas and food surpluses (and lower prices) in other areas. Table 6 also shows that the average yields of maize and sorghum have almost doubled in most countries over the period 1966-2006. Yield increases were large in Burkina Faso, Ethiopia and South Africa and modest in Kenya and Malawi, while yields actually declined in Rwanda. Only in South Africa are maize and sorghum to a certain extent produced with substantial irrigation, machine and fertilisers inputs (Nieuwoudt and Groenewald 2003), resulting in yields more or less corresponding to the high input yield levels indicated earlier by the FAO Agro-ecological zoning project in 1979 (FAO 1979).

Cassava yields are rather high by 1979 FAO standards, and they increased in Malawi, Kenya and Senegal, but declined in Rwanda and Burkina Faso. The yields of beans have only increased in Cameroon and South-Africa. However, total production of beans has increased enormously in SSA as the area under beans has almost tripled (270\%) over the last 40 years (FAOSTAT 2009). In contrast, the large areas under maize and sorghum have
Table 5 The four principal crops with the largest area cultivated in the eight selected countries in period 2005-2007* (areas in million ha)

FAOSTAT 2009; Cash crops in italics

\begin{tabular}{lllllllll}
\hline Country & Crop 1 & Area & Crop 2 & Area & Crop 3 & Area & Crop 4 & Area \\
\hline Burkina F. & Sorghum & 1.4 & Millet & 1.3 & Cotton & 0.7 & Maize & 0.5 \\
Senegal & Millet & 0.7 & Groundnut & 0.7 & Sorghum & 0.2 & Maize & 0.1 \\
Ethiopia & Teff & 2.5 & Maize & 1.7 & Wheat & 1.5 & Sorghum & 1.4 \\
Kenya & Maize & 1.8 & Beans & 1.0 & Coffee & 0.2 & Wheat & 0.2 \\
Malawi & Maize & 1.6 & Beans & 0.2 & Groundnut & 0.2 & Potatoes & 0.2 \\
Rwanda & Plantains & 0.4 & Beans & 0.3 & Sorghum & 0.2 & Sw. potato & 0.1 \\
Cameroon & Sorghum & 0.6 & Maize & 0.5 & Cocoa & 0.4 & Cassava & 0.3 \\
South Africa & Maize & 2.6 & Wheat & 0.7 & Sugarcane & 0.4 & Sunflower & 0.4 \\
\hline
\end{tabular}


Table 6 Yields of food crops*, 1966-2006 (in tha ${ }^{-1}$ )

\begin{tabular}{|c|c|c|c|c|c|c|c|c|}
\hline & \multicolumn{2}{|l|}{ Maize } & \multicolumn{2}{|l|}{ Sorghum } & \multicolumn{2}{|c|}{ Cassava } & \multicolumn{2}{|c|}{ Beans (dry) } \\
\hline & 1966 & 2006 & 1966 & 2006 & 1966 & 2006 & 1966 & 2006 \\
\hline Burkina F. & 0.67 & 1.80 & 0.50 & 1.09 & 5.5 & 2.0 & - & - \\
\hline Senegal & 0.77 & 1.82 & 0.77 & 0.83 & 3.8 & 8.0 & - & - \\
\hline Ethiopia & 1.00 & 2.33 & 0.82 & 1.57 & - & - & 0.71 & 0.71 \\
\hline Kenya & 1.15 & 1.80 & 1.11 & 0.92 & 7.8 & 10.4 & 0.48 & 0.48 \\
\hline Malawi & 1.09 & 1.46 & 0.65 & 0.72 & 7.0 & 17.0 & 0.52 & 0.39 \\
\hline Rwanda & 1.30 & 0.84 & 1.20 & 1.10 & 10.5 & 6.1 & 0.80 & 0.70 \\
\hline Cameroon & 0.76 & 1.89 & 0.80 & 0.91 & 5.4 & 6.3 & 0.44 & 0.88 \\
\hline S. Africa & 1.48 & 3.31 & 0.89 & 2.67 & - & - & 0.83 & 1.29 \\
\hline \multirow[t]{2}{*}{ Average } & 1.28 & 2.27 & 0.75 & 1.24 & 6.1 & 8.7 & 0.64 & 0.60 \\
\hline & \multicolumn{8}{|c|}{ Yield indications under low and high input systems, according to FAO (1979) ${ }^{1)}$} \\
\hline Input level & Low & High & Low & High & Low & High & Low & High \\
\hline Yield range & $0.6-1.7$ & $3-7$ & $0.6-1.3$ & $2-5$ & $2-3$ & $5-13$ & $0.4-0.7$ & $1.5-3$ \\
\hline
\end{tabular}

FAOSTAT 2009. * Three year average yields $1965-1967$ and $2005-2007 ;{ }^{1)}$ Figures for cassava yields are now considered to be much higher for low and high input systems (Fermont 2009)

only increased by $12 \%$ and $13 \%$ in the same period, while the area under cassava increased by $130 \%$. The total area under these four food crops (plus sweet potatoes) increased in the eight countries by about $28 \%$ (FAOSTAT 2009).

Also food consumption shows much variation (Table 7). In Burkina Faso, Ethiopia, Senegal and South Africa, and to a lesser extent Kenya, the staple food consists mainly of grains, notably sorghum and millet for Burkina Faso; teff, maize and wheat in Ethiopia; rice in Senegal and maize in South Africa. Roots and tubers are of major importance in Rwanda and (southern) Cameroon, and of secondary importance in Kenya and Malawi, where maize has always been the dominant crop. However, consumption of roots and tubers in Rwanda and Malawi increased sharply, while, in the 1970 s and early 1980 s, maize contributed more to calorie intake per capita in Malawi than anywhere else in the world (de Graaff 1985; unpublished).

Despite the increase in production of several major staple crops, the calorie intake per capita has decreased in three countries (Kenya, Malawi and Senegal) over the period 1966-2003 and only increased considerably in Burkina Faso. The protein intake per capita has even declined in five countries, particularly in Malawi and Rwanda, possibly due to the above-mentioned shift to consumption of roots and tubers, which contain less protein.

The data on food consumption and calorie intake in Table 7 correspond well with the development indicators on malnutrition and food aid in Table 1, showing that in 2003 Ethiopia, Kenya, Malawi and Rwanda had a relatively high level of malnutrition and received a large amount of food aid per capita. These countries appear to suffer most from food insecurity. Clearly, the calorie intake has not improved in most of these SSA countries as a result of low food security. Crop yields have not increased sufficiently. Burkina Faso appears to have made the biggest strides towards food security in these 40 years, in terms of per capita production increase in calorie intake and protein
Table 7 Consumption of main cereals and roots \& tubers per capita $(\mathrm{kg} / \mathrm{yr})$, and total per capita intake of calories (Kcal/ day) and proteins (g/day) (1966-2003)

FAOSTAT 2009. * Grains considered are maize, millet, rice, sorghum, wheat and tef

* Roots and tubers comprise cassava, potatoes, sweet potatoes and yams

\begin{tabular}{|c|c|c|c|c|c|c|c|c|}
\hline \multirow[t]{2}{*}{ Country } & \multicolumn{2}{|c|}{ Grains* } & \multicolumn{2}{|c|}{ Roots \& tubers* } & \multicolumn{2}{|c|}{ Total calories } & \multicolumn{2}{|c|}{ Total protein } \\
\hline & 1966 & 2003 & 1966 & 2003 & 2003 & Change 66-03 & 2003 & Change 66-03 \\
\hline Burkina F. & 157 & 220 & 15 & 3 & 2515 & 1.40 & 72 & 1.29 \\
\hline Senegal & 186 & 166 & 60 & 18 & 2374 & 0.97 & 60 & 0.88 \\
\hline Ethiopia & 105 & 125 & 15 & 12 & 1858 & 1.06 & 53 & 0.90 \\
\hline Kenya & 146 & 123 & 77 & 60 & 2154 & 0.94 & 59 & 0.87 \\
\hline Malawi & 177 & 142 & 19 & 176 & 2125 & 0.95 & 54 & 0.81 \\
\hline Rwanda & 42 & 30 & 178 & 346 & 2070 & 1.02 & 47 & 0.82 \\
\hline Cameroon & 97 & 103 & 118 & 115 & 2285 & 1.10 & 58 & 1.05 \\
\hline S. Africa & 169 & 180 & 15 & 25 & 2962 & 1.09 & 77 & 1.08 \\
\hline
\end{tabular}


intake, which may be related to livestock production discussed below.

\section{Cash crop and livestock products}

Apart from physical, technological and human factors, food crop production and food security are also affected by the cultivation of cash crops and by rearing livestock. Cash crops bring in cash, which is inter alia used for buying fertilisers and other inputs for food crops and livestock provides manure, makes good use of crop residues and often serves as in-kind savings for future food insecure periods.

In SSA cash crops include crops mostly grown for export, e.g. coffee, cocoa, tea and cotton, but also products for domestic consumption which are sold mainly to processing plants, e.g. sugarcane, oilseeds. Table 5 shows that the area under cash crops is much smaller than the area under food crops. Cash crops are often considered a threat for (replacing) food crop production, as they compete for the same resources. However, apart from generating cash for inputs, a well fertilised cash crop like cotton may be grown in rotation with food crops, as in Burkina Faso, where it has boosted food crop production.

Table 8 shows yield trends for the four major cash crops in the eight SSA countries. While the yields of cotton doubled on the average for all countries, it declined sharply in Ethiopia and a little in Senegal. The yields of groundnut however declined on average although it increased in countries such as Ethiopia, Kenya and South Africa. Combined with the declining areas, it is clear that the importance of groundnut, as a major source of vegetable oil, is declining in SSA. In some countries this is related to the success of cotton, as groundnut and cotton compete for resources in the same areas (Hamasselbé 2008).

A similar mixed trend was shown by coffee yields which increased in Ethiopia and Rwanda and decreased in Cameroon and Kenya. These four countries are all producers of Arabica coffee, although Cameroon produces also large quantities of Robusta coffee. In the 1980s it was clear that most African coffee producing countries did so at high cost with marginal potential for recovery of labour cost (de Graaff 1986). Since then coffee prices have been low and the competition on the world market from Latin America and Asia (e.g. Vietnam) has become more severe, leading to a further decline of the coffee sector in Africa.

Some crops that generate cash to farmers do not appear, or appear insufficiently, in statistics, as they are not supposed to be grown (e.g. qat or Catha edulis, a very important crop in Ethiopia), or because they are passing through informal channels, as happened in the 1980s with sunflower seeds in Kenya, much of which was eventually sold to Arab countries (for chewing), instead of being delivered to the local oil processing plants.

While cash crops in some countries may have had a positive effect on food crop yields through spin-offs of the application of fertilisers to cash crops, e.g. cotton in West Africa (Boussard et al. 2005), this is not a general pattern. However, in most countries, cash crops do play a role in generating earnings that are used for food purchases, although this may sometimes be affected by the gender labour division, whereby men cater for cash crops and women for food crops (Gladwin et al. 2001).

Livestock development may also affect food crop production. It competes with the latter for land, other resources and food as feed, but it can also be complementary in providing draught power and manure in addition to making use of crop residues. Livestock has also traditionally played an important role in food supply, in particular for pastoralist populations, but also other people derive relatively large amounts of protein rich food from livestock. In most countries, herds are still growing, but generally at a lower pace than the human population growth rate. Consequently, domestic meat and milk consumption per capita has declined, with Burkina Faso and to a lesser extent Cameroon as exceptions (Table 9). Ethiopia and
Table 8 Yields of cash crops*, 1966-2006 (in t ha ${ }^{-1}$ )

FAOSTAT 2009. * Three year average yields $1965-1967$ and 2005-2007

\begin{tabular}{|c|c|c|c|c|c|c|c|c|}
\hline & \multicolumn{2}{|c|}{ Cotton } & \multicolumn{2}{|c|}{ Groundnut } & \multicolumn{2}{|c|}{ Coffee } & \multicolumn{2}{|c|}{ Sugarcane } \\
\hline & 1966 & 2006 & 1966 & 2006 & 1966 & 2006 & 1966 & 2006 \\
\hline Burkina $\mathrm{F}$. & 0.25 & 1.09 & 0.56 & 0.79 & & & & \\
\hline Senegal & 1.21 & 1.17 & 0.88 & 0.81 & & & & \\
\hline Ethiopia & 1.94 & 0.89 & 0.51 & 1.09 & 0.24 & 0.76 & 138 & 103 \\
\hline Kenya & 0.23 & 0.43 & 0.60 & 1.24 & 0.57 & 0.26 & 38 & 88 \\
\hline Malawi & 0.30 & 0.88 & 0.82 & 0.71 & & & 80 & 109 \\
\hline Rwanda & & & 0.71 & 0.59 & 0.52 & 0.77 & & \\
\hline Cameroon & 0.56 & 1.17 & 0.82 & 0.61 & 0.41 & 0.26 & & \\
\hline S. Africa & 0.73 & 2.28 & 1.10 & 1.54 & & & 75 & 49 \\
\hline Average & 0.49 & 1.08 & 0.87 & 0.78 & 0.31 & 0.51 & 73 & 58 \\
\hline
\end{tabular}


Table 9 Cattle and sheep and goats population, 1966-2006, in million heads and its ratio with population growth and increase in area cultivated (arable and permanent crops)

\begin{tabular}{|c|c|c|c|c|c|c|c|c|}
\hline \multirow[t]{2}{*}{ Country } & \multicolumn{2}{|l|}{ Cattle } & \multicolumn{2}{|c|}{ Sheep and goats } & \multicolumn{2}{|c|}{ Livestock units (cattle \& shoats) } & \multirow{2}{*}{$\begin{array}{l}\text { Popul. Growth } \\
\text { factor }^{2)}\end{array}$} & \multirow{2}{*}{$\begin{array}{l}\text { Cult. area growtl } \\
\text { Factor }^{2}\end{array}$} \\
\hline & 1966 & 2006 & 1966 & 2006 & $\begin{array}{l}\text { Density }{ }^{1)} \text { : } \\
\text { LU km }{ }^{-2}\end{array}$ & $\begin{array}{l}\text { Change }^{2)} \\
\text { '66-06 }\end{array}$ & & \\
\hline Burkina F. & 2.3 & 8.4 & 3.7 & 18.2 & 44 & 4.0 & 2.86 & 1.84 \\
\hline Senegal & 2.4 & 3.1 & 2.3 & 9.3 & 25 & 1.7 & 3.10 & 0.80 \\
\hline Ethiopia & 25.6 & 42.2 & 43.0 & 40.2 & 46 & 1.5 & 2.85 & 1.40 \\
\hline Kenya & 7.7 & 12.6 & 9.4 & 21.0 & 29 & 1.8 & 3.71 & 2.02 \\
\hline Malawi & 0.4 & 0.8 & 0.6 & 2.0 & 10 & 2.3 & 3.33 & 1.75 \\
\hline Rwanda & 0.6 & 1.0 & 0.6 & 1.8 & 50 & 1.9 & 2.87 & 2.64 \\
\hline Cameroon & 1.8 & 6.0 & 3.1 & 8.2 & 16 & 3.2 & 2.94 & 1.63 \\
\hline S. Africa & 11.2 & 13.6 & 44.2 & 31.5 & 16 & 1.0 & 2.38 & 0.67 \\
\hline Total & 52.0 & 87.7 & 106.9 & 132.4 & & 1.6 & & 1.30 \\
\hline
\end{tabular}

FAOSTAT 2009. ${ }^{1)}$ In 2006. ${ }^{2)}$ Average annual percentage

South Africa have by far the largest herds of sheep and goats, but these have declined in the period 1966-2006. In Senegal, and to lesser extent in Burkina Faso, Malawi, Kenya and Rwanda, there is a shift from cattle to sheep and goats. Only in Kenya and Rwanda has the increase in the cattle population lagged behind the increase in the area cultivated, thus reducing the possible potential for availability of manure and probably animal draught power per hectare.

Livestock still seems to perform, in most countries, a complementary role to crop production. However, the competition for feed in countries with relatively small areas of pasture land and high population density may eventually lead to a stagnation or decline of the cattle population. This may reduce the supply of draught power and manure, which may, in turn, negatively affect crop production. As mentioned above, there is already a relative shift towards small ruminants in several countries.

Burkina Faso and Cameroon, where the increase in livestock numbers has exceeded population growth, are among the three countries (including also South Africa) in which the protein intake per capita increased in this 40 year period.

\section{Major constraints in crop production}

The trends in agricultural development and food security in the past 40 years show that there has been considerable diversity between clusters of countries and individual countries. Countries have been able to increase their crop production so as to keep up with population growth by increasing the area under cultivation and crop yields. The combination of these two growth factors varies from country to country. In Senegal and South Africa the areas cultivated declined but was compensated by an increase in yields, whereas in Rwanda the area cultivated increased but yields stagnated, probably as a result of low soil fertility. Although large in size, the first two countries have much dry land which is less suitable for crop production, and a declining agricultural labour force. Rwanda, a small country, on the other hand is confronted with declining land quality and still relies much on agriculture and manual operations. In this section we will deal with what appear to be the most important constraints in (food) crop production: labour shortage, low soil fertility and land degradation, lack of water resources and insufficient institutional support and these help to explain the various trends and their diversity in the countries and clusters of countries discussed in the previous two sections.

\section{Labour shortage}

Traditionally it was argued that labour and capital were the major constraints in agricultural development in Africa and that there was enough land available. While foreign advisors often warned about the high and sometimes explosive population growth in Africa, local politicians sometimes groped back to the idea of labour shortage and argued that the population should increase (pers. comm.). The impact of labour shortage is felt in particular in timeconsuming activities such as land preparation, which has to be accomplished rapidly at the onset of the unreliable rains, and during the crucial but laborious activity of weeding. Insufficient attention to these activities can be a major explanation for low yields, as noted by Slegers (2008) in Ethiopia and Tanzania. In fact, low yields caused by labour shortage, when it is critically needed, trigger a vicious 
circle, forcing many farm households to seek additional income in off-farm employment, further reducing the man days of labour available for farmwork.

In West African countries, such as Burkina Faso, there is only one rainy season and a long dry season, in which there is underemployment in the rural areas (de Graaff 1996). Seasonal migration and emigration have often become part of the livelihood systems, in which the absence of men during extended periods of the year increases the burden of those remaining on the farm: women, children and the elderly. This vicious circle is further exacerbated by a sharply decreasing average farm size, requiring more inputs to reach self-sufficiency in food production, and by illnesses and premature deaths, as a result of malaria, HIV-AIDS and various tropical diseases (Wilcox and Gubler 2005). The IAASTD (2009) report also refers to the vicious circle of poor health, reduced productivity, etc., facing the most vulnerable groups in agriculture.

Among the eight countries, Burkina Faso has the highest number of emigrants, many of whom work mainly for long periods in the Ivory Coast on coffee and cocoa farms. Malawi had a large number of emigrants working in South African mines until 1988; thereafter migration continued informally. Between 1960 and 2005 South Africa and the Ivory Coast were the countries with the largest inflow of migrants (Naudé 2010). Senegal had immigrants to work in the groundnut sector, but in recent years it has shown a net emigration. Rwanda has faced both emigration and immigration, but for reasons not related to employment (e.g. conflicts).

The vicious circle of labour shortage - low productionemigration etc. could be reversed by improved technology, e.g. animal and mechanical traction, labour-saving threshing and processing devices, etc., but farm size has often become too small for the successful application of improved technology and capital is generally limiting.
Land degradation and soil nutrient depletion

Land degradation and soil depletion may also cause crop production to decline. Cleaver and Schreiber (1994) emphasise the downward spiral of overpopulation-land degradation leading to ever greater poverty and more land degradation. Poor soils are characteristic of many African agricultural zones, and land degradation further impoverishes these soils. Of the several forms of land degradation in Africa, including both water and wind erosion, soil nutrient depletion is probably the most serious one. In his classic work on farming systems in the tropics Ruthenberg (1980) emphasized the importance of maintaining soil fertility, particularly in the semi-arid zones.

Table 10 shows the use of inorganic fertilizers per hectare of cultivated land in the respective countries for three periods and it shows the nutrient balance situation around 1983 as estimated by Stoorvogel and Smaling (1990) and around 2003, according to Henao and Baanante (2006). Fertilizer inputs were extremely low in the 1960s, and are still very low nowadays when compared with the world average of $110 \mathrm{~kg}(\mathrm{~N}, \mathrm{P}$ and $\mathrm{K}) \mathrm{ha}^{-1}$. In general, the use of inorganic fertilizers has been higher in East and Southern Africa than in West Africa, but because of higher extraction of nutrients and high levels of erosion, soil mining has also been more severe in the East African countries. Notwithstanding the fact that the nutrient balance figures are derived from two different sources, it can not be concluded that the situation has improved. The figures of Henao and Baanante for 2003, in the right hand column, are somewhat lower and show less variation than the ones by Stoorvogel and Smaling for 1983, but both gave negative soil nutrient balance for all countries. Despite the increase in fertilizer application over the period 1966 to 2005 (which was minimal before), the nutrient balance situation is presently probably not much better than in 1983. Soil
Table 10 Fertilizer application and nutrient balances in selected countries (kg nutrients per ha*)

*Sum of plant nutrients: $\mathrm{N}$, $\mathrm{P}_{2} \mathrm{O}_{5}$ and $\mathrm{K}_{2} \mathrm{O}$; in nutrient balance shortage is often in relation $\mathrm{N}: \mathrm{P}: \mathrm{K}=45: 15: 40$

1) FAOSTAT 2009; 2)

Stoorvogel and Smaling 1990;

3) Henao and Baanante 2006

\begin{tabular}{|c|c|c|c|c|c|}
\hline & \multicolumn{3}{|c|}{ Fertilizer application ${ }^{1)}$} & \multirow{3}{*}{$\begin{array}{l}\text { Nutrient balance }{ }^{2)} \\
\mathrm{N}+\mathrm{P}+\mathrm{K} \\
1983\end{array}$} & \multirow{3}{*}{$\begin{array}{l}\text { Nutrient balance }{ }^{3)} \\
\mathrm{N}+\mathrm{P}+\mathrm{K} \\
2003\end{array}$} \\
\hline & $\mathrm{N}+\mathrm{P}+\mathrm{K}$ & $\mathrm{N}+\mathrm{P}+\mathrm{K}$ & $\mathrm{N}+\mathrm{P}+\mathrm{K}$ & & \\
\hline & 1966 & 1996 & 2005 & & \\
\hline Burkina Faso & 0 & 6 & 8 & -30 & -43 \\
\hline Senegal & 5 & 8 & 12 & -37 & -41 \\
\hline Ethiopia & 0 & 11 & 14 & -100 & -49 \\
\hline Kenya & 6 & 28 & 35 & -85 & -68 \\
\hline Malawi & 2 & 21 & 23 & -144 & -72 \\
\hline Rwanda & 0 & 0 & n.a. & -129 & -77 \\
\hline Cameroon & 1 & 5 & 8 & -39 & -44 \\
\hline S. Africa & 24 & 49 & 47 & n.a & n.a. \\
\hline Average & 8 & 23 & 29 & -72 & n.a. \\
\hline
\end{tabular}


mining is most severe in Rwanda and Malawi, followed by Ethiopia and Kenya. It is, however, less in the drier West African countries, Burkina Faso and Senegal.

Drought and water scarcity

The climate in most African countries and regions is characterised by high temperatures and low rainfall. Except for Cameroon the amount of renewable water resources per capita is rather limited in the selected countries (Table 11). Burkina Faso and Kenya are the most deprived, with only about $800 \mathrm{~m}^{3}$ per capita per year. The Table also shows that overall water withdrawal, as percentage of the amount of renewable water, the use of water for irrigation and the amount of water available per person outside agriculture are very low, except for South Africa. The fact that the efficiency of water use in agriculture in Africa is much lower than in other continents is partly due to high evaporation as a result of the hot and dry climate, and partly to low and highly unreliable rainfall, which often falls in short but intensive showers. This also causes a high proportion of surface runoff often resulting in loss of more than $50 \%$ of the rainfall.

Surprisingly, both Rwanda, the most densely populated country, and Cameroon, the least densely populated country, show the lowest renewable water withdrawal rates and the smallest irrigated area and water withdrawal rate for irrigation. Senegal and South Africa use relatively much more water for irrigation.

Low and unreliable rainfall explain to a large extent the very low crop yields. The risk of crop failure, due to deficient and untimely rainfall or occasional heavy showers that result in flooding, is extremely high, and farmers are therefore very cautious about sowing and using fertilisers and other inputs. They have, however, traditionally developed strategies to reduce or spread the risk by planting their crops on several plots with different soil types, and by minimizing inputs. And farmers are used to sowing more than once, when the rains come late or when the first rains are followed by a long dry spell (Slegers 2008).
With rainfall patterns already being quite unreliable, climate change is likely to have much effect on rainfall and crop production. At a country level these effects may be dampened to some extent because most countries have several agro-ecological zones. This is probably why in an analysis of annual rainfall and grain yields in Burkina Faso, Rwanda and Ethiopia from 1973 to 2007 (not shown here) it was only in the case of Burkina Faso that a reasonable correlation was found $(R=0.45)$ between these two variables: Burkina Faso has less diversified agro-ecological zones than the other countries. But the variation of rainfall over the years was in all three countries quite high, and yields and production showed increasing fluctuations over this period.

\section{Lack of institutional support}

In the late 1960s, Mosher (1969) argued that in order to get agriculture moving, a progressive rural structure was required. Six important components were highlighted as: - an outlet for farm products;--an adequate farm input supply;--production credit;--extension services, including education/training;--local verification trials to support agricultural research; and farm-tomarket roads. He later emphasized that the existence of rural industries and non-agricultural employment in general would also be important ingredients (Mosher 1971).

Many of these elements still constitute major constraints to crop production in SSA. While the marketing of cash crops is often reasonably efficient, thanks to the link with processing industries and export companies, food crop marketing is more cumbersome because of the perishable nature of the product, and its organisation involving a limited number of private traders who dominate the market. Many governments therefore established parastatal marketing organisations for food crops and promoted agricultural cooperatives, e.g. Kenya, Cameroon, Malawi, but both were not very efficient in food crop marketing for various reasons (FAO 1978).

A major problem in food crop marketing in Africa is that the world trade is dominated by multinational food

Table 11 Water resources and water use in the selected countries

\begin{tabular}{|c|c|c|c|c|c|c|c|c|c|}
\hline Indicator & Unit & B.F. & Sen & Eth & Ken & Mal & Rwa & Cam & S.A. \\
\hline Average annual Rainfall & $\mathrm{mm}$ & 748 & 686 & 848 & 630 & 1181 & 1212 & 1604 & 495 \\
\hline Renewable water Resources & $\mathrm{m} 3 /$ cap./yr & 821 & 3177 & 1512 & 792 & 1164 & 977 & 14957 & 1007 \\
\hline Withdrawal as $\%$ of renewable water & $\%$ & 7.8 & 6.7 & 5.3 & 9.1 & 6.9 & 1.8 & 0.4 & 26.9 \\
\hline Area irrigated as $\%$ of cultivated area & $\%$ & 0.5 & 3.8 & 2.7 & 1.8 & 1.9 & 0.6 & 0.4 & 9.5 \\
\hline Withdrawal for irrigated agriculture & $\mathrm{m} 3 /$ cap./yr & 55 & 198 & 75 & 57 & 64 & 12 & 44 & 171 \\
\hline Water available outside agriculture & $\mathrm{m} 3 / \mathrm{cap} . / \mathrm{yr}$ & 9 & 15 & 5 & 15 & 16 & 6 & 16 & 100 \\
\hline
\end{tabular}

FAO Aguastat, and calculations derived from these statistics 
organisations, and that both the USA and the EU dump their surpluses on the world market against prices that the local African producer cannot compete with. The present rise of food prices, among others because of increased demand for biofuel, could hopefully be beneficial for African food crop producers (but this would of course not help net food purchasers). Cash crop marketing is also hampered by the dominance of a limited number of multinational firms in international trade. Additionally, international commodity agreements (e.g. for coffee) have failed to stabilise markets and to assure a better share for primary producers. Real commodity prices have shown a drastic downward trend in the period 1970-2000, while for some commodities they increased slightly after 2000 (IAASTD 2009).

Whereas the supply of inputs for cash crops, such as fertilisers and pesticides, is often linked to the provision of credit and the marketing of the product, such a mechanism is usually missing for food crops, while the few private traders or the parastatal board are still monopsony suppliers of inputs. The inadequate supply of inputs and credit partly explains low fertiliser application in SSA, as shown in Table 10, and the high incidence of pest and diseases in crop production and high post-harvest losses. Many farmers in SSA are struggling with Striga spp. and other weeds, pests and diseases in their crops.

The lack of all-weather roads is also an impediment for traders and marketing boards. This increases transport costs for food crops in many countries like Kenya and Malawi where pan-territorial pricing policies were applied (Smith 1995). With regard to marketing and transport of inputs and outputs there is a large difference between the land-locked countries and those having their own harbours. Rwanda, Malawi, Burkina Faso and Ethiopia are at a clear disadvantage in that regard. This situation is aggravated when relations with neighbouring countries are disturbed.

Much attention has also been paid to the lack of extension staff and services and the inadequate link between research and extension. In many countries, the Training \&Visit extension system was introduced in the 1980 s, but it was not very successful and was undermined by liberalisation and structural adjustment policies (Green 2006). The impact on agricultural productivity of extension has in general been modest in the developing world and in SSA in particular (Anderson and Feder 2004). The link with research remains weak, and the role of local verification trials, as suggested by Mosher (1969), is still modest.

Land tenure is also seen as an important constraint on agricultural development and investment in soil and water conservation. From colonial times onwards, there have been large differences in farm size and tenure security among small and large farmers. A dual system has come into being with very large estates on prime land and large numbers of very small subsistence farms elsewhere in countries such as Kenya, Malawi and South Africa.

After the land reform in Ethiopia, farmers feared new land redistribution and were reluctant to invest in their land (Benin and Pender 2001). Inheritance laws can work in many different ways. They can cause extreme fragmentation of properties, as in Rwanda, but they can also lead to land consolidation with all land being taken over by the eldest son, as in Burkina Faso. De Zeeuw (1997) found that in Burkina Faso both land borrowers and lenders were free to improve their parcels, except for tree planting, which is considered an act of appropriation.

\section{Opportunities and challenges}

In spite of many constraints and drawbacks, recently some positive trends regarding agriculture and food security can be observed in these SSA countries. While calorie intake declined in some countries over the entire period of 19662003, as shown in Table 7, food consumption per capita (in terms of calories) increased in the 8 countries in the latter half of this period, between 1986 and 2006. Annual population growth decreased in most countries from about $3 \%$ to $2.5 \%$, except in Burkina Faso where it went up to almost 3\%. In South Africa it declined to less than 1\% (World Bank 2009). Gross domestic product increased in most countries faster than population growth, except in Kenya and Rwanda. And agricultural growth in SubSaharan countries in general has accelerated from 2.3\% per year in the 1980 s to $3.8 \%$ per year in the early 2000 s, resulting in lower food aid requirements. But the recent international economic crisis is likely to adversely affect agricultural growth in SSA.

In the past decades various successful interventions have been reported, showing that there is scope for substantially increasing food production in SSA. Considering the above described constraints, such successes are generally built on tackling several constraints at a time, taking advantage of specific local conditions that enabled positive changes in food production or both. These opportunities as well as some other challenges are briefly discussed in this section.

\section{Overcoming labour constraints}

To overcome labour constraints and improve labour productivity, more attention should be paid to labour saving technologies in agriculture in the form of using draught animal and mechanical power. This could be possible on sufficiently large farms. It allows timely planting and cultivation, which can immediately increase productivity. Another advantage of reducing the workload will be that 
children are not required any longer for agricultural work and can go to school. For the minifarms in the densely populated countries, such as Rwanda and Malawi, it would require land consolidation, and access to animal traction or mechanical hire services.

On very small farms the focus could also be directed towards non-conventional agricultural technologies, such as Conservation Agriculture. Bischop-Sombroek et al. (2004) state that "the impact of HIV/AIDS and the severe labour shortage in parts of Africa may act as a catalyst for change, propelling African smallholders down the path of reduced tillage and cover crops towards Conservation Agriculture". They refer to various sources, showing that Conservation Agriculture (with simple tools) could reduce labour inputs considerably, despite the increase of weeding time in some areas. Better crop rotations and crop diversification can also help to spread labour requirements throughout the year and reduce labour peaks.

On the other hand much effort must be made to improve the human health situation, by reducing the incidence and harmful effects of malaria and AIDS. Considerable international resources are nowadays devoted to reaching a break-through in the fight against tropical diseases and hopefully Africa can soon benefit from that. The WHO's 10-year-old Roll Back Malaria campaign already shows promising results. All countries discussed in this paper, except for South Africa and Cameroon, are included in this programme (Bate 2010).

Another major labour constraint to be overcome is that of brain-drain, which has been very high in African countries, in particular in Nigeria, Kenya and Ethiopia. A plea was made by the Network of African Science Academies at the G8 conference in Italy in 2009 to convert the brain-drain into a brain-gain by means of international investment in scientific research and technology and establishing centres of excellence in Africa (NASAC 2009).

\section{Overcoming nutrient scarcity and malnutrition}

By means of adequate soil management and monitoring of nutrient flows, soil nutrient depletion can be brought to a halt (de Jager et al. 1998). Van der Pol (1993) showed for Southern Mali that soil mining in traditional food crop rotations with sorghum and millet was serious, but that rotations with cotton and recommended fertilization rates could reverse nutrient depletion. The "miracle" of the Machakos region in Kenya (Tiffen et al. 1994; Burger and Zaal 2009), following the 'induced innovation concept' of Boserup (1965), shows that crop production can increase as a result of improved soil and water conservation, even under high population growth. However, the Machakos region has some favourable features, which other areas may not have, e.g. good market integration due to proximity to Nairobi.
Farm land in all eight countries shows a (very) negative nutrient balance, in particular of nitrogen, and in most countries livestock development is lagging behind population growth. Taking this into account, one could agree with the investment option suggested by the World Bank to focus more on bean production and on promising soybean production in these Sub-Saharan countries (World Bank 2008b). This could contribute to better land husbandry and to better nutrition. The Soils, Food and Healthy Communities Project in Malawi has already successfully followed this approach (Bourne 2009). As beans by themselves produce low yields per ha, more research is required, particularly in land scarce areas, in locally adapted new mixed cropping systems with good effects on soil fertility.

In connection with this, crops with a high calorie content per ha, such as cassava and enset, could also play an important role in densely populated countries in SSA. To achieve this, the focus should be on further yield increases (already quite successful with cassava in Malawi) and in improved technology to reduce production, processing and marketing costs (Dixon and Ssemakula 2008). Fermont (2009) showed that cassava is not (any longer) the food security crop for poor farmers, grown with little inputs on poor soils, but a crop grown by and suitable for many farmers. Her research supported farmers' perceptions that cassava can have a positive impact on soil fertility, thanks to the recycling of crop residues. This would however require further efforts to eradicate the cassava mosaic disease (InterAcademy Council 2004).

Despite its largely semi-arid climate, Burkina Faso stands out with its high production increase over the period 1966-2006 and also with higher calorie intake per capita as a result. These developments have partly been triggered by agricultural intensification induced by several large scale soil and water conservation activities, combined with increased investment in livestock and tree crops, all meant to improve soil fertility (Reij et al. 2005). Much attention is now paid to composting and use of locally available rock phosphate. Other countries in semi-arid zones can learn lessons from these successful intensification programmes. Lessons can also be learned from successes and failures of soil and water conservation and soil fertility improvement programmes undertaken in countries like Ethiopia, Kenya and Rwanda, and from newly developed Conservation Agriculture initiatives in various countries in Africa, which try to reduce erosion and improve soil organic matter content (Giller et al. 2009).

\section{Overcoming water shortage}

Considering the relative scarcity of water resources in most SSA countries, major efforts should be undertaken by various stakeholders to use all available water efficiently. 
The African continent does not have so many dams, but the ones present are relatively large. However, they are often not fully used for their main purposes: hydro-electricity and irrigation. Only $8 \%$ of their hydro-electricity potential is exploited (ICOLD 2006), and only $13 \%$ of irrigable land in SSA is actually under irrigation (Perry 1997). While South Africa has 539 dams, the other seven countries each have fewer than ten large dams (FAO 2007). Because of the high-cost and socio-economic complexities of large scale irrigation schemes, the emphasis in SSA should be on promotion of small scale irrigation schemes. Consequently, more use could be made of groundwater and where possible on-farm pressurized irrigation technology, as already used in South Africa and Kenya (Svendsen et al. 2008). Among the countries with little irrigation, Rwanda has developed an Irrigation Master Plan while in Cameroon irrigation is concentrated in the dry northern zone and focuses on rice production. An interesting development in mountainous zones situated close to major towns is a shift towards high valued crops on irrigated terraces, as found in Tanzania among others (Malisa et al. 2011).

As the potential for irrigated agriculture is modest in many places, the focus will have to be laid on more efficient use of water in rainfed agriculture through the reduction of high losses of evaporation and runoff. A major role will have to be played by sub-surface water storage in spate-irrigation systems and in water harvesting systems. Water harvesting systems present highly adapted, flexible, low cost solutions which are easy to understand and implement. Water harvesting technologies include both centuries-old systems developed by local knowledge and also new innovative approaches. By stressing the concept of retaining water in buffers, water harvesting management concerns both the blue (surface) and green (sub-surface) water resources (van Steenbergen and Tuinhof 2009). Water harvesting technologies are already widely used in Ethiopia, Burkina Faso, South Africa, Senegal and Kenya, but could be easily expanded in those and in other SSA countries.

The Southern \& Eastern African Rainwater Network (SEARNET) has mapped the potentials of rainwater harvesting technologies in ten countries in SSA (Mati et al. 2006) and it has best-practices, scale-up project sites in Ethiopia, Malawi and Rwanda. Kenya will continue its lead role as a spring board for technology development and dissemination.

\section{Overcoming institutional ineffectiveness}

Among the things that are needed to reach higher production levels are upgrading organisations in the fields of research, extension, input supply and credit, and improving land tenure arrangements. Apart from the technological opportunities mentioned above, there is ample evidence of opportunities to increase production of traditional crops following more focused research activities and local verification trials. Jones (2006) mentions some of these successes: use of specific herbicides to reduce Striga infestation in maize production, tissue culture in bananas reducing diseases, and promotion of new (Nerica) rice varieties and high yielding cassava and pigeon pea varieties. Food production can also benefit from a further integration of (preferably leguminous) trees into annual food crop systems, now referred to as Evergreen Agriculture (Garrity et al. 2010).

This shows that there is potential to increase production provided that institutional inefficiencies are removed. The drawback remains that in most countries in Africa the government budget is limited and its institutions are relatively weak. Also the private service sector is insufficiently developed, and therefore services like input supply, marketing, credit and extension remain inadequate. The success stories show that these institutional aspects should be tackled at the same time as the agronomic improvements and preferably through local initiatives.

Since secure, individual and transferable land titles are regarded as important prerequisites for rural development, the government of Ethiopia has started to introduce land certification. This process of land certification is considered to be an example for other African countries as it is decentralized, participatory, cost effective and nondiscriminatory towards the poor or women (Deiniger et al. 2008). The government of Rwanda, with its very small farms, has in a land law (Minerena 2005) made recommendations for land consolidation (minimum farm size of $1 \mathrm{ha}$ ) and, in order to cater for the high population growth, is also encouraging family planning (Bidogeza et al. 2011).

\section{A big push or a green revolution?}

A special case is formed by the recently established Millennium Villages in SSA countries like Ethiopia, Kenya, Malawi, Rwanda and Senegal, where reports mention the doubling of maize yields (from 1.7 to $4.1 \mathrm{t}$ $\mathrm{ha}^{-1}$; Sanchez et al. 2009) thanks to the so-called "big push"; i.e. huge investments in external inputs to boost agricultural production.

These results depend largely on external support and are unfortunately not easy to scale up, but there are also local organisations and communities, referred to as "Bright Spots", that have initiated some supporting activities themselves and have managed to improve production, food security and their natural resources simultaneously (Penning de Vries 2005). This term was previously used by Haggblade and Hazell (2010), who recently edited a book on Successes in African Agriculture, in which they show among other matters the very promising results in breeding and production of 
cassava, maize and cotton in some parts of Africa. In order to cope with stagnating food production in Africa, people now talk about the need for a Green Revolution. The Alliance for a Green Revolution in Africa (AGRA), chaired by Kofi Annan, strives to join forces in order to reach higher levels of food security in Africa and to achieve as many as possible of the Millennium Development Goals.

Landlocked Malawi has been the first country in Africa to implement a national green revolution strategy (Smale 1995). As a result, the national maize production in 20062008 was each year more than double that of the drought affected year 2005. Many important lessons were learned from this successful programme (Denning et al. 2009). However this intensification came at a substantial cost, since the government heavily subsidized $\mathrm{N}$-fertilizer and improved maize seed. Snapp et al. (2010) show that much more attention should be paid to ecosystem services and they suggest focussing much more on intercropping of maize with various legumes to improve the soils, sequester carbon and improve fertilizer response. They also show that farmers have in that regard preference for a semi-perennial and annual legume intercrop/maize rotation.

Schmitz and Wolvekamp (2009) argue that one should be careful in copying the Green Revolution recipe, as applied in Mexico and Asia. Here, the combination of high yielding varieties, fertilisers, irrigation, etc. led to substantial increases of production, but also to an increasing gap between the rich and the poor. With more fertile soils and higher and better distributed rainfall, the Asian countries could develop irrigation schemes and intensify crop production through double and triple cropping. This is not so easy in Africa, although there are some countries and agro-ecological zones where it would be possible. Interestingly, the major production increases in the past 40 years have often been found among minor crops, indicating that diversification is also an important strategy for the generally risk averse farmers.

It should be in any case a sustainable revolution, which should consider marketing conditions, (re)investment in research, extension and farmer organizations, and agroecological friendly policies, focusing on diversity of crop varieties and making use of indigenous farming practices, such as crop mixtures and rotations. (de Schutter 2010). Where possible, use should be made of indigenous and successful soil and water conservation and water harvesting measures (Reij and Waters-Bayer 2001).

\section{Conclusions}

More emphasis should be given to the constraints and opportunities in each individual country. General recipes for the whole of SSA should be avoided. This paper illustrates that the eight selected countries show consider- able differences in the development and present status of their agricultural production and food security.

The relatively small countries, Rwanda and Malawi, have the highest percentage of their land under crops, thanks to the fact that the entire area of these two countries is (sub) humid. These countries are also among those with the lowest average farm size. To cope with low farm size many households have gradually switched from the cultivation of grains to root and tuber crops. Probably due to a lack of grazing areas, there is also a shift from cattle to small ruminants. These latter two developments may explain the present low and declining protein intake per capita. While in Malawi yields did increase, in Rwanda they did not. In Rwanda the area cultivated increased almost threefold, leaving no room for further expansion. Improving soil fertility (by combined use of inorganic and organic fertilizers), more protein rich crops (e.g. legumes), consolidating farm size, e.g. through new inheritance laws, and family planning should be high on the agenda in these countries.

Ethiopia and Kenya also belong to the countries with a very low average farm size, and they show a low intake of both calories and proteins per capita, which has been declining further. Their country figures mask the great heterogeneity of agro-ecological zones, ranging from high potential farming zones with good soils and rainfall, to semi-arid and arid zones which are often subject to droughts affecting both the human and livestock populations. The farmers in the high potential zones have to some extent benefited from the cash crops coffee and tea in years with good prices and from sales of milk from dairy cattle to buy fertilisers for their food crops, but the farmers in the (semi-)arid marginal zones face many obstacles in maintaining food security and natural resources. Water harvesting and soil and water conservation techniques and optimal crop-livestock integration should play a key role here.

The West African countries Burkina Faso and Senegal have shown both similar and dissimilar agricultural development features. In both countries the cotton area and cotton production have increased considerably. Through crop rotation and fertilization this has also helped to boost food production (sorghum, millet and maize). In Senegal the total area cultivated declined as a result of rapid urbanization and declining employment in agriculture. In Burkina Faso, however, the area cultivated increased. As crop production and livestock numbers in Burkina Faso increased faster than the population, the calorie and protein intake per capita increased considerably over the period 1966-2006 in this country. Burkina Faso and Senegal should probably pursue their present development paths, while preparing themselves for on-going climate change, which already affected them in the 1970s and 1980s.

The last two countries Cameroon and South Africa are relatively large and have both very specific characteristics. Cameroon can be considered in various respects as a small copy 
of Africa as a whole because of its German, French and English colonial heritage, its different agro-ecological zones (Africa's highest rainfall in the south-west and Sahelian conditions in the north), and the largest variety of main crops as shown in Table 3. In coffee cultivation one finds both the highland Arabica and lowland Robusta varieties there. Average farm size is comparatively large, population growth relatively modest, production increase just above average and food aid quite low. There appears not to be an imminent food security problem, but the country figures mask the regional differences.

South Africa is no longer an agriculture-based, low income developing country, with its relatively high GDP per capita and HDI (Table 1). While most of the land in the country is considered to be agricultural, livestock is more important than crops. The area cultivated has actually decreased in the past 40 years and crop production has not kept pace with population growth, despite the fact that yield levels are much higher than in the other countries. The number of livestock units did not increase during this period. Much effort will be required to reduce the prevalence of HIV/AIDS, which is partly responsible for the low population growth, and ways have to be found to ensure that a new generation of commercial farmers will use abandoned farm land in order to step up agricultural production and ensure domestic food security in the future (Vink and Kirsten 2003).

This paper shows that trends in agriculture over the past 40 years have been mixed and that trends in food security show a decline in per capita calorie and protein intake in some of the eight countries. While there are some general lessons that can be learned from the past development and specific success stories on the continent, each of the countries has its own particular set of constraints and opportunities that need to be assessed and explored. The continent's own initiatives, such as that of the Alliance for a Green Revolution in Africa, should be supported by all, while being adapted for each particular country. It is hoped that this will make all countries food secure in the next decades.

Open Access This article is distributed under the terms of the Creative Commons Attribution Noncommercial License which permits any noncommercial use, distribution, and reproduction in any medium, provided the original author(s) and source are credited.

\section{References}

Anderson, J. R., \& Feder, G. (2004). Agricultural extension: good intentions and hard realities. The World Bank Research Observer, 19(1), 41-60.

André, C., \& Platteau, J. P. (1998). Land relations under unbearable stress: Rwanda caught in the Malthusian trap. Journal of Economic Behavior and Organization Vol, 34, 1-47.

Bate, R. (2010). World Bank Matrix (Malaria Booster Program). An analysis for Africa Fighting Malaria. Resident Fellow, American Enterprise Institute for public policy research (AEI), Washington.
Benin, S., \& Pender, J. (2001). Impacts of land redistribution on land management and productivity in the Ethiopian highlands. Land Degradation and Development, 12, 555-568.

Bidogeza, J. C, Berentsen, P. B. M., de Graaff, J., \& Oude Lansink, A. G. J. M. (2011). Bioeconomic modelling of the influence of family planning, land consolidation and soil erosion on farm production and food security in Rwanda. Submitted to Agricultural Systems.

Bischop-Sombroek, C., Kienzle, J., Mariki, W., Owenya, M., \& Ribeiro, F. (2004). Conservation Agriculture as a labour saving practice for vulnerable households. Babati and Karate districts, Tanzania. FAO and IFAD, Rome.

Boserup, E. (1965). The Conditions of agricultural growth: The economics of agrarian change under population pressure. London: Allen \& Unwin.

Bourne, J. K. (2009). The Global Food Crisis; the End of Plenty. National Geographic Magazine June, 2009.

Boussard, J. M., Daviron, B., Gérard, F., \& Voituriez, T. (2005). Food security and agricultural development in Sub-Saharan Africa: building a case for more support. Background document. CIRAD for FAO.

Burger, K., \& Zaal, F. (Eds.). (2009). Sustainable land management in the tropics: explaining the miracle $(210 \mathrm{pp})$. Farnham: Ashgate.

Cleaver, K. M., \& Schreiber, G. A. (1994). Supplement to reversing the spiral: The population, agriculture, and environment nexus in Sub-Saharan Africa. Washington DC: World Bank.

de Graaff, J. (1985). Introduction to the economics of maize (unpublished manuscript).

de Graaff, J. (1986). The economics of coffee (p. 294). Wageningen: Pudoc.

de Graaff, J. (1996). The price of soil erosion: an economic evaluation of soil conservation and watershed development. PhD Thesis, Wageningen University. Mansholt Studies No. 3. Leiden: Backhuys Publishers.

de Graaff, J., van der Mijl, J. P., \& Nibbering, J. W. (1999). Farm survey design in the Sahel; experiences from Burkina Faso. Quarterly Journal of International Agriculture, 38, 35-52.

de Jager, A., Nadwa, S. M., \& Okoth, P. F. (1998). Monitoring nutrient flows and economic performance in African farming systems (NUTMON); 1 Concepts and methodologies. Agriculture, Ecosystem \& Environment, 71, 37-48.

de Schutter, O. (2010). Report submitted by the special rapporteur on the right to food. United Nations, Human Rights Council, A/ $\mathrm{HRC} / 16 / 49$.

de Zeeuw, F. (1997). Borrowing of land, security of tenure and sustainable land use in Burkina Faso. Development and Change, 28(3), 583-595.

Deiniger, K., Ayalew, D., Holden, S., \& Zevenbergen, J. (2008). Rural land certification in Ethiopia: process, initial impact and implications for other African countries. World Development, 36, 1786-1812. Washington DC.

Denning, G., Kabambe, P., Sanchez, P., Malik, A., Flor, R., et al. (2009). Input subsidies to improve smallholder maize productivity in Malawi; towards an African Green Revolution. PLoS Biol. 7(1). doi:10.1371/journal.pbio.1000023.

Devereux, S., \& Maxwell, S. (Eds.). (2001). Food security in SubSaharan Africa. London: ITDG.

Dixon, A. G. O., \& Ssemakula, G. (2008). Prospects for cassava breeding in Sub-Saharan Africa in the next decade. Journal of Food, Agriculture and Environment, 6(3\&4), 256-262.

Dixon, J., Gulliver, A., \& Gibbon, D. (2001). Farming systems and poverty; improving farmers' livelihoods in a changing world. Rome: FAO and World Bank.

Dorward, A. (2010). Future-agricultures. Institute of Development Studies at the University of Sussex, Brighton: www.future-agricultures.org/ index.php?option=com_content $\&$ view=article $\&$ id=340:andrew-dor ward\&catid $=95$ : soil-fertility \&Itemid $=535$ 
Ehui, S., \& Pender, J. (2005). Resource degradation, low agricultural productivity, and poverty in sub-Saharan Africa: pathways out of the spiral. Agricultural Economics, 32, 225-242.

FAO (1978). Final Report of the Marketing Development Project (FAO/KEN/75/005). Phase I. Coordinating committee of the project, Nairobi, Kenya.

FAO. (1979). Rapport sur le projet relatif aux zones agro-écologiques. Vol. 1. Méthodologie et résultats pour l'Afrique. Rome: FAO.

FAO. (2006). The state of food insecurity in the world: eradicating world hunger-taking stock ten years after the World Food Summit. Rome: FAO.

FAO. (2007). FAO Aquastat dams in Africa. Rome: FAO.

FAOSTAT (2009). http://faostat.fao.org Rome: FAO

Fermont, A. M. (2009). Cassava and soil fertility in intensifying smallholder farming systems of East Africa. PhD Thesis Wageningen University.

Garrity, D. P., Akinnifesi, F. K., Ajayi, O. C., Weldesemayat, S. G., Mowo, J. G., Kalinganire, A., et al. (2010). Evergreen Agriculture: a robust approach to sustainable food security in Africa. Food Security, 2, 197-214.

Giller, K., Witter, E., Corbeels, M., \& Tittonell, P. (2009). Conservation agriculture and smallholder farming in Africa: the heretics' view. Field Crops Research, 114, 23-34.

Gladwin, C. H., Thomson, A. M., Peterson, J. S., \& Anderson, A. S. (2001). Addressing food security in Africa via multiple livelihood strategies of women farmers. Food Policy, 26, 177-207.

Green, E. (2006). Extension service, agricultural development and smallholder agricultural production in Malawi: 1930s to 2000, Department of Economic History, Stockholm University, Stockholm.

Haggblade, S., \& Hazell, P. B. R. (Eds.). (2010). Successes in African agriculture; lessons for the future. Baltimore: Published for the International Food Policy Research Institute (IFPRI) by Johns Hopkins University Press.

Hamasselbé, A. (2008). La revalorisation de la filière arachide dans la zone soudano-sahélienne du Nord Cameroun. Tropicultura, 26 (4), 200-205.

Henao, J., \& Baanante, C. (2006). Agricultural production and soil nutrient mining in Africa: implications for resource conservation and policy development. Muscle Shoals: IFDC.

IAASTD. (2009). Agriculture at a crossroads. Global and synthesis reports. International assessment of agricultural knowledge, science and technology for development. Washington, DC: Island. 590 and $80 \mathrm{pp}$ respectively.

ICOLD (2006). http:/www.icold-cigb.org

InterAcademy Council. (2004). Realizing the promise and potential of African agriculture. Science and technology strategies for improving food security and agricultural productivity in Africa. Executive Summary. Amsterdam: IAC.

Jones, M. (2006). An agricultural research perspective on poverty, innovation policies and agricultural development in sub-Saharan Africa. EGDI Policy, poverty and agricultural development in Sub-Saharan Africa Workshop, Frösundavik, Sweden.

Karshenas, M. (1999). Agriculture and economic development in SubSaharan Africa and Asia. Working paper, SOAS, University of London, London.

Kidane, W., Maetz, M., \& Dardel, P. (2006). Food security and agricultural development in sub-Saharan Africa; building a case for more public support. Rome: FAO.

Malisa, E. T. N., Mattee, A. Z., \& de Graaff, J. (2011). Soil and Water Conservation Practices in the Uluguru Mountains: The Influence of High Value Crops Promotion. Not yet published manuscript.

Mati, B., De Bock, T., Malesu, M., Khaka, E., Oduor, A., Nyabenge, M., \& Oduor, V. (2006). Mapping the potentials for Rainwater Harvesting technologies in Africa: A GIS overview on development domains for the continent and ten selected countries.
Technical Manual No. 6 Nairobi, Kenya: World Agroforestry Centre (ICRAF), Netherlands Ministry of Foreign Affairs.

Minerena (2005). Organic law determining the use and management of land in Rwanda. Law No. 08/2005 of 14/07/2005. Ministry of Lands Environment, Forestry, Water \& Mines, Kigali.

Mosher, A. T. (1969). Creating a progressive rural structure: to serve a modern agriculture. New York: Agricultural Development Council.

Mosher, A. T. (1971). To create a modern agriculture. New York: Agricultural Development Council.

NASAC (2009). Brain drain in Africa. Joint Statement by the Network of African Science Academies (NASAC) at the occasion of the G8 meeting in Italy, Rome.

Naudé, W. A. (2010). The determinants of migration from Sub-Saharan countries. Journal of African Economies, 19(3), 330-356.

Nieuwoudt, L., \& Groenewald, J. (Eds.). (2003). The challenge of change; agriculture, land and the South African Economy. University of Natal Press: Pietermaritzburg. 290 pp.

Penning de Vries, F. W. T. (editor) (2005). Bright spots demonstrate community successes in African agriculture. Working paper 102. International Water Management Institute, Colombo.

Perry, E. (1997). Low-cost irrigation technologies for food security in Sub-Saharan Africa. In Irrigation technology transfer in support of food security. Rome: FAO.

Reij, C., \& Waters-Bayer, A. (Eds.). (2001). Farmer innovation in Africa; a source of inspiration for agricultural development. London: Earthscan.

Reij, C., Tappan, G., \& Belemvire, A. (2005). Changing land management practices and vegetation on the Central Plateau of Burkina Faso (1968-2002). Journal of Arid Environments, 63, 642-659.

Ruthenberg, H. (1980). Farming systems in the tropics. Oxford: Clarendon. 424 pp.

Sanchez, P. A., Denning, G. L., \& Nziguheba, G. (2009). The African Green Revolution moves forward. Food Security, 1, 37-44.

Sanders, J. H., Shapiro, B. I., \& Ramaswamy, S. (1996). The economics of agricultural technology in semiarid Sub-Saharan Africa. Baltimore: The John Hopkins University Press.

Schmitz, T., \& Wolvekamp, P. (2009). Does Africa need a Green Revolution; poverty, land degradation and the Millenium Development Goals. Policy note. Amsterdam: Both Ends.

Slegers, M. F. W. (2008). Exploring farmers' perceptions of drought in Tanzania and Ethiopia. PhD thesis. Tropical Resource Management Paper No. 93. Wageningen University, The Netherlands.

Smale, M. (1995). Maize is life; Malawi's delayed green revolution. WorldDevelopment, 23(5), 819-831.

Smith, L. D. (1995). Malawi: reforming the state's role in agricultural marketing. Food Policy, 20(6), 561-571.

Snapp, S. S, Blackie, M. J., Gilbert, R. A., Bezner-Kerr, R., \& Kanyama-Phiri, G. Y. (2010). Biodiversity can support a greener revolution in Africa. PNAS, 107(48).

Stoorvogel, J. J., \& Smaling, E. M. A. (1990). Assessment of soil nutrient depletion in Sub-Saharan Africa:1983-2000. Report No. 28. Wageningen: Winand Staring Centre.

Svendsen, M., Ewing, M., \& Msangi, S. (2008). Africa infrastructure country diagnostic. Summary of Background paper 4. IFPRI/ World Bank, Washington.

Tiffen, M., Mortimore, M., \& Gichuki, F. (1994). More people, less erosion: Environmental recovery in Kenya. London: John Wiley and Sons.

UNDP (2010). What will it take to achieve the millennium development goals? An international assessment. United Nations Development Programme, New York.

Van der Pol, F. (1993). Soil mining: an unseen contributor to farm income in Southern Mali. Bulletin 35. Amsterdam: Royal Tropical Institute. 
van Steenbergen, F., \& Tuinhof, A. (2009). Managing the water buffer for development and climate change adaptation. Groundwater Recharge, Retention, Reuse and Rainwater Storage. BGR, the Co-operative Programme on Water and Climate (CPWC) and the Netherlands National Committee IHP-HWRP.

Vink, N., \& Kirsten, J. (2003). Agriculture in the national economy. In L. Nieuwoudt \& J. Groenewald (Eds.), The challenge of change; agriculture, land and the South African Economy. Pietermaritzburg: University of Natal Press.

Westphal, E., Embrechts, J., Ferwerda, J. D., van Gils-Meurs, H. A. E., Mutsaers, H. J. W., \& Westphal-Stevels, J. M. C. (1985). Cultures vivrières tropicales; avec référence spéciale au Cameroun. Wageningen: Pudoc.

Wilcox, B. A., \& Gubler, D. J. (2005). Environmental change and infectious diseases. Environmental \& Poverty Times No 4.

World Bank. (1989). Sub-Saharan Africa: from crisis to sustainable growth. Washington, D.C.: World Bank.

World Bank. (2008a). World development report 2008. Washington, D.C.: World Bank.

World Bank. (2008b). Sustainable land management sourcebook. Washington, D.C.: World Bank.

World Bank (2009). World development indicators. Washington, D.C., World Bank. http://web.worldbank.org/wbsite/external/datastatistics

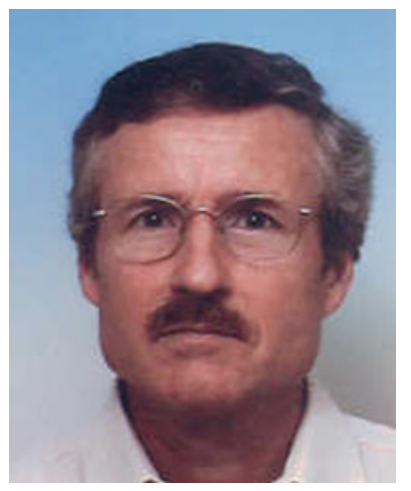

Jan de Graaff is associate professor with the Land Degradation and Development group of Wageningen University. He holds an Msc in Development Economics and his $\mathrm{PhD}$ Thesis (1996) was entitled "The price of soil erosion: the economics of soil conservation and watershed development". He worked for many years in countries in Africa and Asia for FAO and for the Royal Tropical Institute in the fields of food strategy studies and economics of soil and water conservation, before joining Wageningen University. $\mathrm{He}$ lectures on impact evaluation of land and water management and is involved in several EU and other research projects in southern Europe and Africa. He is author of several books and many articles and is a member of the editorial board of the Land Use Policy journal.

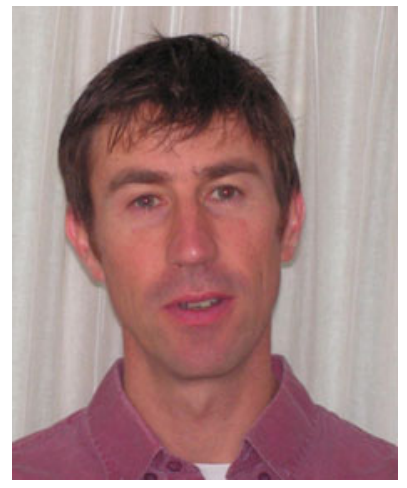

Aad Kessler is a specialist in sustainable rural development, natural resources management and the adoption of soil and water conservation practices. $\mathrm{He}$ has 10 years working experience in Latin America, where he worked for FAO in Chile and Peru, and did $\mathrm{PhD}$ research and project coordination in Bolivia. $\mathrm{He}$ has also worked in West Africa. His focus is on harmonizing farmers' and development agencies' intervention strategies, and the coordination of multi-stakeholder platforms. He is currently working as teacher and researcher at Wageningen University in the area of Sustainable Land Management Policies, with special emphasis on governance, social capital and multi-stakeholder collaboration. He coordinates a research project on "Scaling up of Sustainable Land Management in the highlands of Kenya and Tanzania" and several $\mathrm{PhD}$ projects in Ethiopia and Tanzania among others.

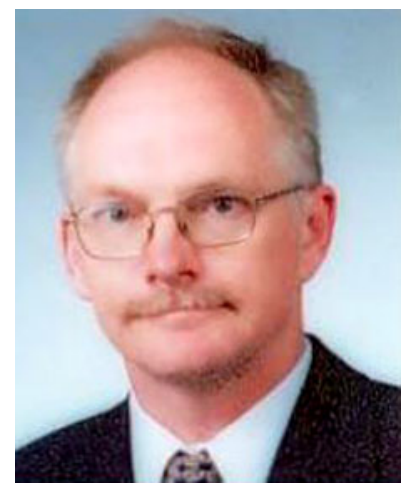

Jan Willem Nibbering is a development cooperation expert who has spent much of his professional life in research and advisory work in the fields of natural resource management and rural development in Indonesia, Pakistan, Burkina Faso, Venezuela and Bolivia. He holds a $\mathrm{PhD}$ in human geography from the Australian National University, defending a thesis on land management in an upland area in Java (1992). In 2003 he joined the Dutch Ministry of Foreign Affairs and became senior policy advisor at the Directorate General for Development Cooperation. He is currently stationed in The Hague and is working on capacity development policies, decentralisation, public-private partnerships and local economic development. He is married and has two daughters. 